\title{
Spatial Patterns of Co-Infection and Tuberculosis/HIV in Ceara, Brazil
} \author{
Ferreira Pires ${ }^{5}$ \\ ${ }^{1}$ University Hospital Walter Cantídio, Brazil \\ ${ }^{2}$ Federal University of Ceara, Brazil \\ ${ }^{3}$ Federal Institute of Education, Brazil \\ ${ }^{4}$ Public Health School of Ceará, Brazil \\ ${ }^{5}$ University Center UNIFAMETRO, Brazil
}

Dalila Augusto Peres ${ }^{1 *}$, Monica Cardoso Façanha ${ }^{2}$, Brazil Antonio Viana Junior ${ }^{1}$, Rogerlândio Francisco Martins De Melo ${ }^{3}$, Janet Romão Dos Santos ${ }^{2}$, Mauricélia Lima Silveira ${ }^{2}$, Marciano Gonçalves De Sousa ${ }^{4}$ and Cristiane

Submission: July 01, 2019; Published: August 22, 2019

"Corresponding author: Dalila Augusto Peres, University Hospital Walter Cantídio - Empresa Brasileira Hospital Services, Fortaleza, Ceará, Brazil

\begin{abstract}
Introduction: The tuberculosis and human immunodeficiency virus (HIV) spatial analysis, based on Morbidity and Mortality date, Contributes to the knowledge of socio-environmental risks and the identification of the most vulnerable areas.

Purpose: Identify the spatial distribution tuberculosis and VERIFY Conglomerates of the existence of tuberculosis and tuberculosis/HIV coinfection cases.

Methods: Ecological study with spatial analysis of tuberculosis cases. The population was composed by tuberculosis cases in Patients older than 15 years, between the years of 2005 and 2014, that lived in Ceará. The data collection was made in the SINAN and in the Mortality Information System (SIM), being informed the diagnoses and deaths Caused by tuberculosis between 2005 and 2014.

Results and Discussions: The spatial analysis Showed the concentration of Municipalities with high risk for tuberculosis in the Health Regions of Sobral, Fortaleza, Caucaia, Maracanaú, Cascavel and Itapipoca. In the spatial autocorrelation two clusters of high risk for tuberculosis Were identified. The concentration of municipalities with high risks for tuberculosis/HIV coinfection are described in the Macro regions of Health and Sobral Fortress, and in the municipalities of Tauá acid, and Orós Jaguaribe, the spatial correlation two clusters identified in the mentioned macro regions.
\end{abstract}

Conclusion: This study priorities defined geographic areas for the control of tuberculosis mortality and morbidity and Showed That the geographic information system technology can be used by health managers in the planning and monitoring program actions of tuberculosis.

Keywords: Tuberculosis; Acquired immunodeficiency syndrome; Spatial Analysis

\section{Introduction}

Morbidity due to tuberculosis (TB) in developed countries has intensified and expanded in the Asian and American continents under the influence of Acquired immunodeficiency syndrome (AIDS), the bacillus drug resistance, social and economic inequality of patients under funding of health services [1], being a current public health problem resulting from a dynamic process of individual and collective factors related to the conditions of life and access to services saúde [2,3].

Tuberculosis is considered a priority public health problem, with an annual average of 73,000 new cases per year in Brazil between 2005 and 2014. In Ceará, the incidence of tuberculosis was 38.7 new cases per 100,000 inhabitants in 2014, above the national average of 33.5 cases $/ 100,000$ inhabitants [4], and only $60.6 \%$ of respiratory symptoms were examined reflecting the need for increased detection of cases of tuberculosis [5]. Ceará is the third state in the Northeast region in number of priority municipalities for tuberculosis control in Brazil [6].

The transmission of HIV and tuberculosis is influenced by human contacts have intensified over the years, in commercial, business and tourism activities. The areas with the highest number of people with HIV exposure are located close to the Brazilian Northeast coast, mainly related to sexual transmission. Regarding tuberculosis, the areas of highest number of cases are in urban areas, pockets of low socioeconomic conditions, and/or municipalities with low human development index (HDI) [7].

Spatial analysis, from morbidity and mortality data, contributes to the knowledge of the social and environmental risks and 
identification of vulnerable areas. Whereas the developing TB and $\mathrm{TB} / \mathrm{HIV}$ reflects the social development of a given population, it is important to understand the occurrence of this disease for programming of health activities, according to the interaction of individuals and social space, considering the level of poverty, health conditions, migratory movements and the aging population as well as the organization and management in health services locals [8].

Given the above, this study aimed to identify the spatial distribution of tuberculosis by checking the existence of clusters of cases of TB and TB/HIV in order to identify areas of greatest vulnerability to illness in the territory and support the planning of health actions and control measures.

\section{Method}

Ecological study with spatial analysis of cases of tuberculosis recorded in the System for Notifiable Diseases Information System (SINAN), and deaths with tuberculosis as underlying or associated cause, the Mortality Information System (SIM). The study period was from 2005 to 2014 for the occurrence of death or diagnosis of tuberculosis.

They included all cases of tuberculosis, aged 15 and over, living in municipalities of Ceará, or deaths diagnosed with tuberculosis as underlying or associated cause. We considered the case of tuberculosis, that confirmed by laboratory testing and/or clinical-epidemiological for surveillance purposes recorded in the SINAN, and died of tuberculosis as underlying or associated cause, that encoded between A15 and A19 of the 10th revision of the International Classification Diseases (ICD-10), reported in part I (lines a, b, c, d) and in part II of the death certificate entered in the SIM.

Ceará is in Brazil's northeastern region, comprising 184 municipalities, with an estimated population of $8,904,459$ inhabitants in 2015. The state is the third country with the largest number of extremely poor or destitute people, and the illiteracy rate was $18.8 \%$ of the population. According to the 2010 IBGE census, the population density of Ceara was 56.76 inhabitants $/ \mathrm{km}^{2}$, with higher population concentration in the metropolitan area of Fortaleza and some municipalities in the south of Ceará, being the most densely populated Fortaleza, Maracanaú, Juazeiro, Eusebius and Pacatuba $[9,10]$.

The incidence of tuberculosis was obtained from the average of new cases and the prevalence of coinfection TB/HIV from the average of new and old cases recorded in information systems, the study period, the population of the town of residence of according to the Brazilian Institute of Geography and Statistics (IBGE) based on the national census 2010.

Analysis of the spatial distribution of the indicators was carried out through thematic maps that had the unit of analysis municipalities of Ceará, from the digital loop 2010, according to the IBGE cartographic base. The indicators were estimated by em- pirical Bayesian method, which enabled smooth random effects resulting from the calculation of indicators for small areas and populations, and annual fluctuations and considered the spatial correlation between neighboring areas [11], available in version 4.2.2 software Terraview, domain público [12].

The spatial correlation analysis was performed by the Moran Global Index, in which the positive values (between 0 and +1 ) indicate direct correlation, i.e. that there is spatial dependence and identify areas of clusters with similar risks how the indicators analyzed [13]. It was used as the criterion of significance $p$ value below 0.05 .

The Moran scatterplot was used to compare each municipality with its neighbor. The areas located in the quadrants Q1 (high-high) and Q2 (low-low) denote positive spatial autocorrelation, i.e. municipalities with similar values to the neighbors about the analyzed indicators, featuring spacious [13] aggregates. For spatial autocorrelation analysis, we used the local Moran index of smoothed indicators, graphical analysis through Moran Map, which showed only the municipalities that showed statistical significance $(\mathrm{p}<0.005)$.

The geographic information system is used ArcGIS version 9.3 (Environmental Systems Research Institute- ESRI Resdlands, CA) for cartographic data analysis and calculation of the global and local spatial autocorrelation index. The construction of thematic maps was taken by ArcGIS program and the analysis of data from these maps and tables.

The data were obtained from the Center for Information and Analysis on Health Coordination of Promotion and Health Protection of the Department of Health of Ceará (SESA), with the latest update of the systems on 23 October 2015. The survey was conducted according to the principles Resolution 466/2012 of the National Health Council was approved by the Research Ethics Committee of the Federal University of Ceará, according to opinion No. $1,292,605 / 2015$.

\section{Results}

In the period from 2005 to 2014 it was recorded 41107 cases of tuberculosis in SINAN and SIM. All municipalities in Ceará registered at least one new case of tuberculosis. The average incidence of tuberculosis in Ceará was 39.7 new cases/100,000 inhabitants in the study period and varied in the different municipalities from 4.2 to 110.0 new cases/100,000 inhabitants.

Spatial analysis of the incidence showed concentration of municipalities with high risk for tuberculosis in the macro-region of Sobral Health and Fortaleza. In macro-region of Sobral, the highest concentration of municipalities with high risk was in the health regions of Sobral and Camocim Crateús. In macro-region of Fortaleza, the highest concentration was in the health regions of Fortaleza, Caucaia, Maracanaú and Itapipoca, Ceará above the average. The municipalities that are in the Health macro-region of East Coast/Jaguaribe have a lower risk for the disease. 
In Figure 1, it is observed that the distribution of the coefficient softened incidence of tuberculosis, which ranged from 10.6 to 74.5 new cases/100,000 inhabitants in Ceará. Having a cutoff tuberculosis incidence average in Ceara (39 new cases/100,000 inhabitants) during the study period, the Health area of Fortaleza showed all municipalities with high incidence smoothed for tuberculosis, Itaitinga being, with 74 new cases; Fortaleza, with 61 new cases; Eusebius, with 55 new cases; and Aquiraz, with 48 new cases/100,000 population (Figure 1).

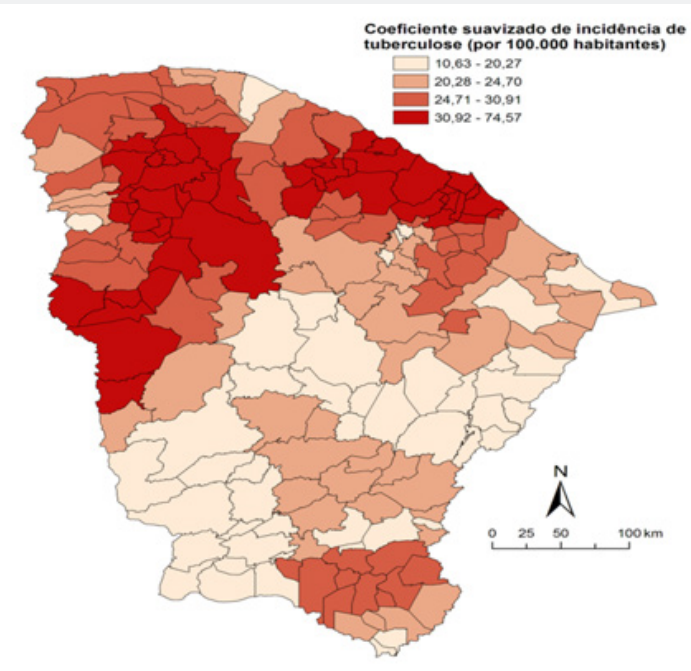

Fonte: Secretaria de Saúde do Ceará (SESA)|

Figure 1: Smoothed coefficient of mean incidence of tuberculosis per 100,000 inhabitants according to the municipality of residence after the relationship with SINAN TB, SIM and SINAN AIDS / TB, Ceará, from 2005 to 2014.

It was observed that the Caucaia health region also exhibited concentration of municipalities with high risk for tuberculosis, in which four of the ten municipalities had an incidence greater than the average of Ceará, being Caucaia with 51 new cases, Paracuru with 45 new cases are Gonçalo do Amarante with 44 new cases and Pentecost with 43 new cases/100,000 inhabitants.

Health region of Maracanaú presented three of its nine municipalities with higher incidence of tuberculosis than the state of Ceará, where 55 new cases exhibited Maracanaú, Pacatuba with 43 new cases and Maranguape with 40 new cases/100,000 inhabitants. Health region Itapipoca exhibited two counties at high risk for tuberculosis, among the seven in this region, being Uruburetama with 55 new cases and Umirim with 43 new cases/100,000 inhabitants.

Sobral Health region also exhibited concentration of municipalities with high risk for tuberculosis, where nine of the $24 \mathrm{mu}$ nicipalities of this region showed an incidence greater than the av- erage of Ceará. The city of Sobral showed 75 new cases/100,000 inhabitants, and eight other surrounding municipalities it also exhibited high incidence, such as fork, with 62 new cases/100,000 inhabitants and Coreaú, with 42 new cases/100,000 inhabitants.

Health region Itapipoca exhibited two counties at high risk for tuberculosis, among the seven in this region, being Uruburetama with 55 new and Umirim with 43 new cases. Already the health region of Cascavel presented a single municipality with high risk for tuberculosis the city of Pacajus, with 42 new cases. Municipalities of Crateús health region had a mean smoothed incidence of tuberculosis greater than 30 new cases/100,000 inhabitants, though lower than the average of Ceará, highlighting the municipalities of Poranga, Ararendá, New Russian, Middle and New Crateús.

Table 1 shows the municipalities with the highest incidence of tuberculosis in Ceará the study period, as well as its prevalence of TB/HIV in these districts.

Table 1: Municipalities with higher average smoothed TB incidence and smoothed mean prevalence of TB / HIV co-infection, Ceará 2005 to 2014.

\begin{tabular}{|c|c|c|}
\hline Município & Incidência TB Suavizada & Prevalência TB/HIV Suavizada \\
\hline Sobral & 75 & 0,8 \\
\hline Itaitinga & 74 & 5,8 \\
\hline Forquilha & 62 & 5,2 \\
\hline Fortaleza & 62 & 4,1 \\
\hline Alcântaras & 58 & 6,1 \\
\hline Eusébio & 56 & 4,3 \\
\hline Meruoca & 56 & \\
\hline
\end{tabular}


Annals of Reviews and Research

\begin{tabular}{|c|c|c|}
\hline Groaíras & 56 & 4,0 \\
\hline Maracanaú & 55 & 5,5 \\
\hline Uruburetama & 55 & 1,1 \\
\hline Massapê & 53 & 3,7 \\
\hline Mucambo & 52 & 3,7 \\
\hline Caucaia & 51 & 5,2 \\
\hline Cariré & 51 & 1,3 \\
\hline
\end{tabular}

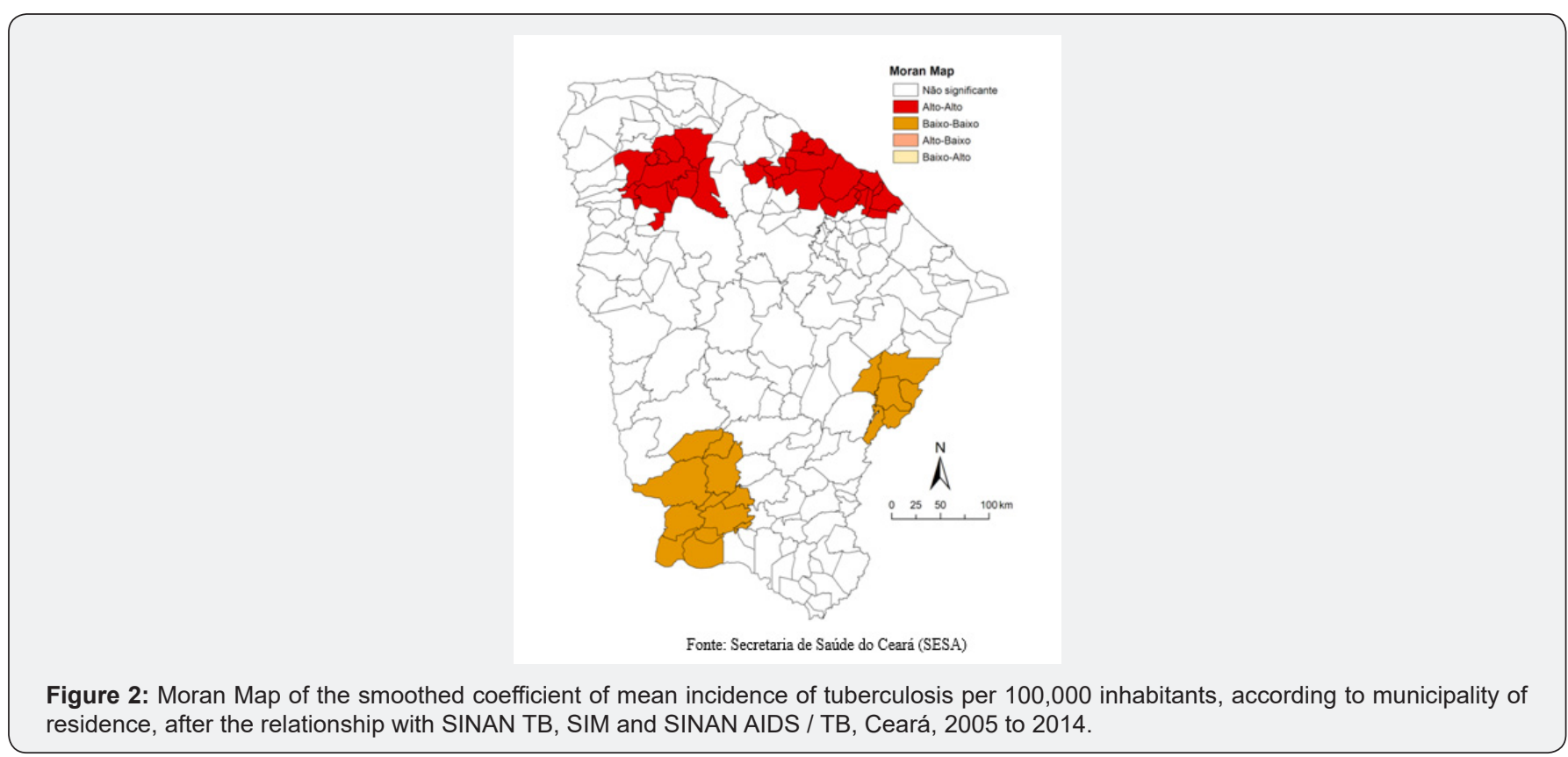

The existence of spatial autocorrelation coefficient of the smoothed average incidence of tuberculosis showed Moran's index of 0.6740 and $p<0.0001$, which indicates the existence of a pattern of positive spatial dependence in the incidence of TB globally in the cities tend to be more similar to municipalities than the neighbors further away. The local Moran index identified spatial clusters (clusters) risk area for tuberculosis, shown in Figure 2 with the Moran Map, allowing the visualization of similarity between neighboring municipalities. The spatial correlation analysis Moran site (Figure 2) confirms findings in cities with a high incidence of clusters displayed in Figure 1. During the study period,

The cluster of high risk for tuberculosis covered the municipalities of Sobral, Santana do Acaraú, Massapê, Meruoca, Alcantaras, Coreaú, Mucambo, Cariré, Groaíras and fork (Figure 2), all in Sobral Health region. The other cluster covered municipalities Health region of Fortaleza (Itatinga, Eusebius, Aquiraz and Fortaleza) Health region Caucaia (Paraibapa, Paracuru, São Gonçalo do Amarante, São Luís do Curu, Pentecost, Itapagé and Caucaia) Maracanã (Maranguape and Pacatuba Maracanau), rattlesnake (Pindoretama, Horizon) and Health region Tapioca (Umirim and Uruburetama), according to Figure 2.

Clusters of municipalities with low TB incidence rates were located in the Health area of Limoeiro do Norte (Alto Santo Jaguaribara, Iracema, Potiretama, Pereiro and Ererê) of Taua (Arnei- roz, Aiuaba), Iguatu (Catarina and Saboeiro) and Crato (Antonina North Field Sales, saltpeter, Araripe Potegi, Tarrafas, and Assaré Altaneira) in Figure 2.

By analyzing the prevalence of co-infection TB/HIV 100,000, it was observed that $140(76 \%)$ of Ceara municipalities at least one registered case of coinfection TB/HIV. The average prevalence in Ceará was 3,1casos of co-infected TB/HIV per 100,000 population, the study period. The average concentration distribution shown prevalence of municipalities with high risk for co-infection TB/HIV in the macro region of Sobral Health and Fortress. In macro-region of Sobral, the highest concentration of municipalities with high risk was in the health regions of Sobral, Acaraú and Crateús. In macro-region of Fortaleza, the highest concentration was in the health regions of Fortaleza, Caucaia, Maracanaú, Cascavel, Aracati, Ceará above the average.

The Tauá town in the macro-region of Central Hinterland and Jaguaribe municipalities, Ico and Orós, the macro-region of Cariri and Jaguaribe, also showed high risk for co-infection TB/HIV. The municipalities with the lowest risk for TB/HIV co-infection are distributed in the macro-regions of the East Coast Health/Central Jaguaribe and Sertao.

Figure 3 refers to the distribution coefficient smoothed prevalence of co-infection TB/HIV, which met a range from 0.1 to 6.1 
cases of TB/HIV 100,000. With the cut-off point the mean prevalence in Ceará (3.1 cases/100,000 inhabitants) during the study period, the Health area of Fortaleza showed all municipalities with high prevalence smoothed average for coinfection TB/HIV, and Eusebius, with 6.1 cases Aquiraz, with 5.9 cases, Fortaleza and Itaitinga with 5.8 cases $/ 100,000$ inhabitants.

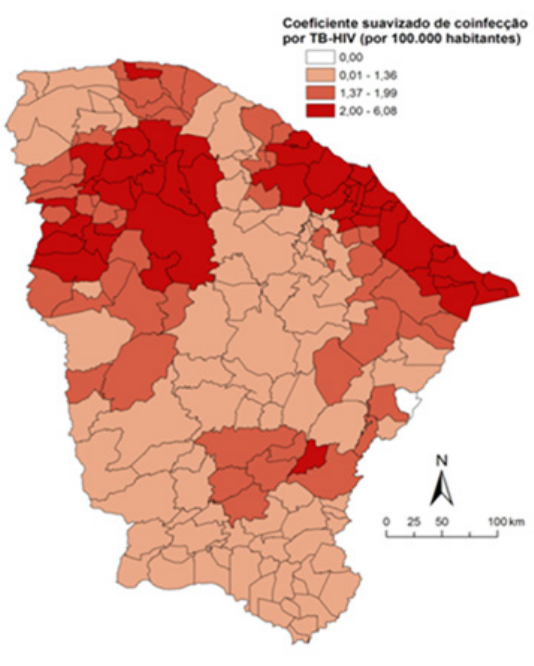

Fonte: Secretaria de Saúde do Ceará (SESA)

Figure 3: Smoothed coefficient of mean prevalence of tuberculosis / HIV coinfection per 100,000 inhabitants according to the municipality of residence, after the relationship with SINAN TB, SIM and SINAN AIDS / TB, Ceará, 2005 to 2014.

Health region of Maracanaú presented three of its nine municipalities with prevalence of coinfection TB/HIV larger than the state of Ceará. Maracanaú showed 5.5 cases Pacatuba and Maranguape with 3.4 cases $/ 100,000$ inhabitants. The municipality of Caucaia showed 5.2 cases/100,000 inhabitants.

Sobral Health region also exhibited concentration of municipalities with high risk of co-infection TB/HIV, wherein eight of the 24 districts of this region showed that the average prevalence greater Ceará. The municipality of Meruoca showed 4.3 cases /100.000 inhabitants, and eight other surrounding municipalities it also exhibited high prevalence, being the largest in Fork, with 4.2 cases /100.000 inhabitants and Massapê, with 3.7 cases/100,000 inhabitants. The only municipality of Rattlesnake health region with high risk for co-infection TB/HIV was the city of Horizonte, with 3.2 cases $/ 100,000$ inhabitants.

The existence of spatial autocorrelation coefficient of the smoothed average prevalence of coinfection TB/HIV was highlighted by the Global Moran index, which showed Moran's index of 0.6951 and $p<0.0001$, which indicates the existence of a dependency pattern in the positive spatial prevalence of co-infection TB/HIV globally, in which municipalities tend to be more similar to municipalities than the neighbors further away.

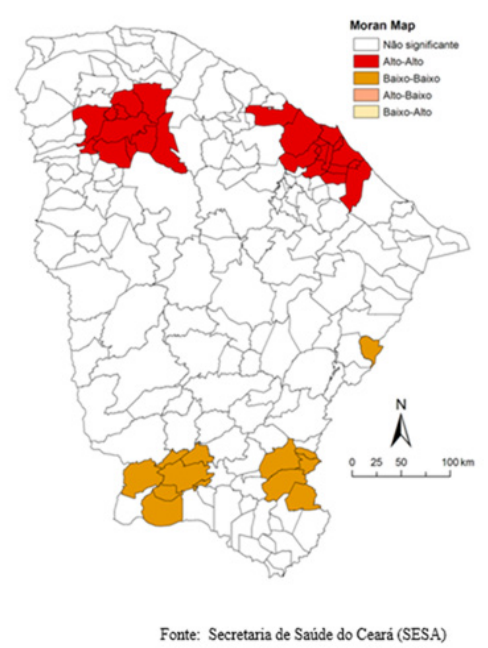

Figure 4: Moran Map of the smoothed coefficient of the average prevalence of tuberculosis / HIV coinfection per 100,000 inhabitants, according to the municipality of residence, after the relationship with SINAN TB, SIM and SINAN AIDS / TB, Ceará, from 2005 to 2014. 
The spatial correlation analysis Moran location (Figure 4) supports the findings of municipalities conglomerates with high prevalence of co-infection TB/HIV seen in Figure 4. During the study period, we identified the existence of two regions of clusters with high risk (Q1-high-high) in the macro-regions of Sobral and Fortaleza.

The cluster of high risk for tuberculosis covered the municipalities of Sobral, Santana do Acaraú, Massapê, Meruoca, Alcantaras, Coreaú, Mucambo, Cariré, Groaíras and fork, all in Sobral Health region. The other cluster covered municipalities Health region of Fortaleza (Itatinga, Eusebius, Aquiraz and Fortaleza) Health region Caucaia (São Gonçalo do Amarante and Caucaia) Maracanaú (Maranguape, Pacatuba, Maracanaú and Guaiúba), Cascavel (Pindoretama, rattlesnake) according to Figure 4.

Clusters of municipalities with low coefficients of prevalence of coinfection TB/HIV were located in Crato Health Region (North Antonina, Field Sales, Araripe, Potegi, Tarrafas, Assaré and Altaneira), Ico (shoal, Ipaumirim, Lavras da Mangabeira ) Fen of Holy (Aurora and Clay) and Northern Limon (Potiretama), (Figure 4).

\section{Discussion}

The spatial distribution of mean incidence of tuberculosis showed heterogeneity in the municipalities of the various health regions of Ceará, in the period of the study, in which there were new cases in all municipalities. The highest incidences of tuberculosis occur in cities of Fortaleza and Sobral macro health regions, which are the most populous state [14].

Overcrowding affects the occurrence of greatest tuberculosis incidence, considering that $75 \%$ of the Northeast's population lives in urban areas along the coast, where are located the capitals and metropolitan regions. In this context, TB is favorable influenced by agglomerations and rapid urbanization, which are added to the bad housing conditions and nutrition [8].

The northeast is a region with intense social inequalities, according to social indicators and urban infrastructure, where $77 \%$ of the municipalities of this region add more than half of the population with low socioeconomics conditions [8]. Overall, the incidence of tuberculosis is distributed quite unevenly with major regional and local disparities associated with socioeconomic inequalities and unsatisfactory conditions of access to health services [15].

The results of this study identified two high risk of tuberculosis clusters, the first in ten municipalities of Sobral health region and another in Fortaleza. The city of Sobral, Ceará northwest belongs to meso, with a population of 188000 inhabitants in 2010 and population density of 88 inhabitants $/ \mathrm{km}^{2}$, with $88 \%$ urbanization rate. It is the richest municipality, concentrates $89 \%$ of gross domestic product (GDP) of the micro-region, although it has $11 \%$ of its population with per capita monthly household income of up to $\$ 70,00[16]$.
In the industrial center of Sobral there are 153 footwear manufacturing industries, cosmetics, cement, mining, soft drinks, etc. It is the most developed city of the micro-region, and the most developed according to the state, according to health indicators, education, quality of life and GDP per capita. In the health area, has ten hospitals serving the population of the northern region, with ratio of two doctors per 1,000 inhabitants, a total of 91 health facilities. In education has the country's educational standard developed focuses middle and high schools, the various areas [16]. The areas with the highest number of tuberculosis cases in the city of Sobral are areas of risk due to low socioeconomic status, poor housing and families numerous [17].

The other nine municipalities (Santana do Acaraú, Massapê, Meruoca, Alcantaras, Coreaú, Mucambo, Cariré, Groaíras and fork) that formed clusters with Sobral are small municipalities with population ranging from 5 to 17 thousand inhabitants, with population density 24-91 inhabitants/km. They have fewer health facilities, 8-20 health/municipality, and the worst human development index (HDI), with positions 33-157 in the state ranking. The urbanization rate was $32 \%$ to $71 \%$ in these municipalities in 2010. Noteworthy is the municipality of Massapê, which is the second most populous municipality and richer the micro-region, and the municipality of Santana do Acaraú is less developed [16].

The second cluster at high risk for tuberculosis was identified in Fortaleza and 19 municipalities in the health regions of Fortaleza, Maracanaú, Caucaia, Cascavel, Itapipoca, within the metropolitan area of Fortaleza. This is constituted by a major population center, with great political and economic importance, due to the concentration of industrial center in the municipalities along the BR-116 and port complex of Pecém [18].

This region is undergoing rapid changes and corresponds to the fifth largest metropolitan area in Brazil, with socio-spatial disparities resulting from the restructuring process based on private investment in agribusiness, industry and tourism, stimulating competition between cities to the detriment of development and cooperation intermunicipal [18].

In this process, the lack of planning and urban management hinders access to urban infrastructure and social facilities/health, associated with worse living conditions of people and goods flows, increasing social and environmental vulnerabilities. Thus, in the metropolitan region of Fortaleza there are areas with large housing estates, larger slums next to industrial areas as well as poor conditions of housing in communities on the banks of rivers and lakes, with people entered the labor market informal [18].

Fortaleza is located on the north coast of Ceará, merely with Caucaia, Eusébio, Aquiraz, Maracanaú, Pacatuba, Itaitinga, with a population of over two million people in 2010 and a population density of 7,786 inhabitants $/ \mathrm{km}^{2}$, with the municipality with best state of the HDI. It presents $5 \%$ of the population with per capita monthly household income of up to $\$ 70.00$ and concentrates 305 health facilities, as well as industries, schools and universities [16]. 
The results reflect the state and metropolitan capital are important spaces with decisive for the transmission of tuberculosis, whereas pockets of poverty in these areas pose challenges for tuberculosis control, as are areas of intense social inequalities and agglomerations humans [8]. The identified clusters are presented as the most vulnerable areas to for tuberculosis, which involves conditions of geographic space, poor access to health services and individual factors as well as the movement of personas [19].

The results showed that there is a high concentration area with high prevalence of co-infection TB/HIV in the macro-health Sobral and Fortress, alone and in the cities of Tauá acid, and Orós Jaguaribe. The areas with greater exposure to HIV are located near the coast in the Northeast, related to sexual transmission, and areas with greater vulnerability to tuberculosis add in pockets of low socioeconomic conditions, urban areas and municipalities with low IDH [7].

The coinfection vulnerability to TB/HIV related to the epidemiological situation of two epidemics in which a aggravates the situation of the other, less favored population in constant movement, influenced by the conditions of life and job [20]. The results showed spatial correlation to coinfection TB/HIV into two clusters: the first being involving twelve districts (Itaitinga, Eusebio, Aquiraz, Fortress, Caucaia, San Gonzalo Amarante, Maracanaú, Pacatuba, Maranguape Guaiuba, Pindoretama and rattlesnake).

The tourism and promote the movement of financial resources, can also cause spread of diseases like AIDS, because of quotas in movements in periods of high season in tourist regions, justifying the spatial correlation of AIDS in Ceará coastal municipalities. Other points from the spread of HIV/AIDS are the Southeast Northeast return to their hometowns, as well as intensification of internal migration processes in municipalities of metropolitan areas and commuting, as well as tourism sexual [21].

The second cluster identified at high risk of co-infection TB/ HIV was in ten municipalities of Sobral health region (Santana do Acaraú, Massapê, Meruoca, Alcantaras, Coreaú, Mucambo, Cariré, Groaíras, Fork and Sobral). The cluster at high risk for AIDS was identified in the municipalities of Ceará located in transport and interconnection means such as BR 222, which begins in the state capital and runs through several municipalities to reach the Piaui and may be influenced by traffic caminhoneiros [21]. This group is most vulnerable, to be in constant motion and may have difficulty in accessing information and AIDS prevention attitudes.

The relationship between AIDS cases in children from Fortaleza and low average monthly income, high percentage of people in poverty, illiterate range, are important elements of social vulnerability identification and little access to information to preventives [22] attitudes.

Indicators related to income, education and population density are associated with tuberculosis in the different levels of spatial aggregation, both by the characteristics of geographical areas under study, such as poverty, which is a heterogeneous phenomenon with type of variation and magnitude between regions and barrios [3].

Considering the identification of high-risk clusters for TB and co-infection HIV, says the need to establish inter pacts to establish control strategies tuberculosis and AIDS, reflecting on social space, influenced by migratory movements, urban areas, socioeconomic conditions and risk behavior for addecimate [21].

The municipalities with the lowest average incidence of tuberculosis and prevalence of coinfection were concentrated in the macro-health of the Wild Center and Jaguaribe, with exceptions of some municipalities, raising the discussion of the need for active case finding and improving access to health services and diagnostic methods, and active surveillance in the municipalities without reporting cases of tuberculosis [19].

\section{Conclusion}

The spatial analysis showed concentration of municipalities with high risk for tuberculosis in the regions of Sobral Health, Fortaleza, Caucaia, Maracanaú, Cascavel and Itapipoca. In spatial autocorrelation, we identified two high-risk clusters for tuberculosis. The concentration of municipalities with high risk for co-infection TB/HIV have been described in the macro-health Sobral and Fortaleza, and alone in the municipalities of Taua, Ico, Orós and Jaguaribe, the spatial correlation identified two clusters for high-risk TB/HIV.

This study defined priority geographic areas for the control of tuberculosis morbidity and showed that the geographic information system technology can be employed by health managers in planning and monitoring of programmatic actions of tuberculosis.

The identification of tuberculosis clusters should be used for health planning by managers, as the spatial analysis shows the importance of the production of disease and death from tuberculosis in urban social space, allocation of financial resources primarily in these municipalities in Ceará and investment public policies to reduce social inequity.

Some limitations of this study involve the use of secondary data from health information systems, in which the variables can be filled inaccurately or incompletely. In spatial analysis, we used the city as a unit of analysis, and in those municipalities with small populations can occur random fluctuations of the occurrence of cases of tuberculosis, we used the empirical Bayesian approach to alleviate these effects and to minimize this problem.

Despite the limitations, the results of this study show consistency with existing knowledge about tuberculosis, as well as being highly representative, since it included the cases of tuberculosis SINAN and all deaths in which TB was recorded as primary or associated cause of death of SIM, Ceará.

\section{References}

1. Rodrigues AMS, Scatena LM, Vendramini SHF, Canini SRMS, Villa TCS, et al. (2012) Avaliação do acesso ao tratamento de tuberculose por 
coinfectados ou não pelo vírus da imunodeficiência humana. Rev Esc Enferm USP 45(5): 1163-1169.

2. Global tuberculosis report 2014. World Health Organization.

3. San Pedro A, Oliveira RM (2013) Tuberculose e indicadores socioeconômicos: revisão sistemática da literatura. Rev Panam Salud Publica 33(4): 294-301.

4. Secretaria de Vigilância em Saúde-Ministério da Saúde (2015) Detectar tratar e curar: desafios e estratégias brasileiras frente à tuberculose. Boletim Epidemiológico 46(9): 1-17.

5. Secretaria de Saúde do Estado do Ceará (2015): Tuberculose. Fortaleza, Boletim epidemiológico, p. 6.

6. Secretaria de Vigilância em Saúde-Ministério da Saúde (2014) 0 controle da tuberculose no Brasil: avanços, inovações e desafios. Boletim Epidemiológico 45(2): 1-13.

7. Rodrigues júnior AL, Ruffino-netto A, Castilho EA (2014) Distribuição espacial do índice de desenvolvimento humano, da infecção pelo HIV e da comorbidade AIDS-tuberculose: Brasil, 1982 - 2007. Rev Bras Epidemiol 17(2): 204-215.

8. Barbosa IR, Pereira LMS, Medeiros PFM, Valentim RS, Brito JM, et al. (2013) Análise da distribuição espacial da tuberculose na região Nordeste do Brasil, 2005-2010. Epidemiol Serv Saúde 22(4): 687-695.

9. Ceará em mapas (2007) Fortaleza: Instituto de Pesquisa e Estratégia Econômica do Ceará.

10. Estados (2016) Instituto Brasileiro de Geografia e Estatística-IBGE Brazil.

11. Santos SM, Souza WV (2007) Introdução à estatística espacial para a Saúde Pública. Ministério da Saúde, Brasília.

12. TERRAVIEW 4.2.2 (2016) São José dos Campos, SP: INPE, Brazil.

13. Druck S, Carvalho MS, Câmara G, Monteiro AMV (2004) Análise espacial de dados geográficos. Planaltina: Empresa Brasileira de Pesquisa Agropecuária.
14. Coordenadorias regionais de saúde (2010). Fortaleza: Secretaria Estadual de Saúde do Ceará.

15. Viana PVS (2014) Tuberculose no Brasil: Uma análise dos dados de notificação, segundo macrorregião e raça/cor, para o período 20082011. Fundação Oswaldo Cruz, Escola Nacional de Saúde Pública Sergio Arouca, Brasil.

16. Perfil Básico Municipal (2014) Fortaleza: Instituto de Pesquisa e Estratégia Econômica do Ceará

17. Farias EJS, Albuquerque IMN, Araújo RA, Soares JSA, Linhares MSC (2013) Análise epidemiológica dos casos de tuberculose notificados no município de Sobral- CE no período de 2007 a 2011. Sanare 12(1): 33-39.

18. Costa MCL, Pequeno R (2015) Fortaleza: transformações na ordem urbana. Observatório das metrópoles.

19. Pinto ML, Silva TC, Gomes LCF, Bertolozzi MR, Villavicencio LMM, et al. (2015) Ocorrência de casos de tuberculose em Crato, Ceará, no período de 2002 a 2011: uma análise espacial de padrões pontuais. Rev Bras Epidemiol 18(2): 313-325.

20. Santos NSGM, Santos MLSG, Vendramini SHF, Villa TCS, Ruffino-netto A, et al. (2014) Tuberculose e análise espacial: revisão da literatura. Cienc Enferm 20(2): 117-129.

21. Paiva SS (2013) Distribuição espacial e determinantes sociais de saúde na população com Aids no Ceará [Tese]. Fortaleza: Universidade Federal do Ceará, Faculdade de Farmácia, Odontologia e Enfermagem, Departamento de Enfermagem, Programa de Pós-Graduação em Enfermagem, Doutorado em Enfermagem.

22. Lopes EM, Pedrosa NL, Holanda ER, Almeida RLF, Kerr LRFS, et al. (2015) Aids em crianças: a influência dos diferenciais socioeconômicos no município de Fortaleza, Ceará, Brasil. Cadernos de Saúde Pública 31(9): 2005-2016.

\section{Your next submission with Juniper Publishers will reach you the below assets}

- Quality Editorial service

- Swift Peer Review

- Reprints availability

- E-prints Service

- Manuscript Podcast for convenient understanding

- Global attainment for your research

- Manuscript accessibility in different formats

( Pdf, E-pub, Full Text, Audio)

- Unceasing customer service

Track the below URL for one-step submission https://juniperpublishers.com/online-submission.php 